\title{
Impact of Integrated Farming System on the Socio-Economic Status of Farmers under 'Mera Gaon Mera Gaurav (MGMG)'Programme in Bishnupur District of Manipur, India
}

\author{
Suparna Dey*, Daya Ram, M. Kunjaraj Singh and N.Okendro Singh \\ College of Agriculture, Central Agricultural University, Iroisemba, Imphal, India \\ *Corresponding author
}

\section{Keywords}

Impact, Integrated Farming System,

Socio-personal,

Socio-economic,

Development

Article Info

Accepted:

18 September 2021

Available Online:

10 October 2021

\section{A B S T R A C T}

As India is facing the challenge of continuous rise in demand of agricultural production with the fixed size of land holding, it became imperative to come up with strategic approaches to meet the growing concern. Therefore, in order to achieve rural development and to alleviate the gap between demand and supply, Integrated Farming System was implemented as one of the vital tool under MGMG programme in potential areas. Keeping in view the scopes, the present study was conducted in Bishnupur District, Manipur. An Ex-post facto research design was adopted for the study. From the three villages of Bishnupur district, a total of 120 respondents were drawn following purposive and simple random sampling method. The objective of the study was to study the socio-personal profile of MGMG farmers and impact of Integrated Farming System on their socioeconomic status. The data collected by using the structured interview schedule were encrypted, tabularized and analysed statistically. An analysis of the selected characteristics of the MGMG farmers revealed that majority of the farmers were middle aged small farmer educated upto high school having medium; organizational participation, farming experience, innovation proneness, risk orientation, mass media exposure, extension contact, annual income and economic motivation and they preferred radio over DAO, Bishnupur as the regularly used source of information.

\section{Introduction}

Agriculture, with its allied sectors, constitutes the largest source of livelihoods in India. About 70 per cent of its rural households rely on agriculture for their living, with 82 per cent of farmers being small and marginal. As the Indian economy has grown diversifically, agriculture's contribution to GDP has steadily declined from 1951 to 2011. While achieving food sufficiency in production, India still accounts for one fourth of the world's hungry people and shelter over 190 million undernourished people. Incidence of poverty is now pegged at near about 30 per cent. While agriculture in India has achieved grain self-sufficiency but farming is yet resource intensive, cereal centric and regionally biased. Therefore, India needs to improve its management of agricultural practices on 
multiple fronts. Improvements in performances in agriculture can increase income of farming households, diversify production of crops, empower women, strengthen agricultural diversity and productivity and design of careful prices and subsidy policies that can encourage the production and consumption of nutrient rich crops. In context to restrict high degree of uncertainty in income and employment in relation to mono cropping in crop production, it is imperative to evolve suitable strategy for augmenting the income of the small and marginal farmers by combining different enterprises at farm level to increase the productivity and supplement the income.

The population is increasing in constant rate without any chance of increase in land areas. The income from cropping for an average farmer is hardly sufficient to sustain his family for which the farmer has to be assured of a regular income for a reasonable standard of living by including other enterprises. Diversification of agricultural livelihoods through agri-allied sectors like forestry, fishery, vermicomposting etc. may enhance livelihood opportunities; strengthen resilience and consequent to a rise in labour force participation in the sector apart from prevention from the threat of the declining trend in the average size of farm holding.

Hence, adoption of Integrated Farming System is a prime focus which is truly apt to enhance the economic options among smaller farms for a labour surplus economy in rural sector for maximizing employment opportunities in order to uplift the landless, small and marginal farmers, who constitute about 84 per cent of total farmers. Therefore, the main goal of Integrated Farming System i.e. integration of farm enterprises often suggested as one of the means for rapid economic development in India (Anonymous, 2019).
Among the Seven Sister States of North-East India Manipur has a large share of the total state domestic product from agriculture and hence 22.13 per cent of employments out of the total workers are provided by the sector. To its contrary, only 7.41 per cent of the geographical area of the state is in use for cultivation purpose. As majority of the farmers in these villages are engaged in integration of two or more than two enterprises to earn the living such as crop production; rearing of livestock and fish production etc. for proper dissemination of the technology and guidance, five farmers were selected as beneficiaries under MGMG in each village to bridge with the rest of the farmers. Keeping in view of these scopes, a study entitled "Impact of Integrated Farming System on the Socio-Economic Status of Farmers under 'Mera Gaon Mera Gaurav (MGMG)' Programme in Bishnupur District of Manipur" was undertaken with the objective to study the socio-personal profile of MGMG farmers.

\section{Significance of the study}

The study is expected to elucidate the impact of IFS on the socio-economic status of farmers under MGMG programme which is purely based on the opinions expressed by the farmers. Furthermore, efforts were also made to study the socio-personal profile of MGMG farmers that may be useful to the extension workers to influence the impact positively. The findings of this study will provide vital instructions about the characteristics of the MGMG farmers to the voluntary, private and government agencies for the development of suitable extension strategies for boosting the socio-economic status.

\section{Materials and Methods}

The present study was conducted in Nambol block of Bishnupur District in Manipur with a 
total of 120 respondents drawn by following purposive and simple random sampling method.

\section{Selection of district}

Out of the sixteen districts in Manipur, Bishnupur District was selected purposively for the present investigation because the district has more than half of the beneficiaries and highest nos. of villages under adoption of the programme MGMG in the state.

\section{Selection of blocks}

Bishnupur District comprises of three blocks out of which Nambol block was purposively selected for the present investigation as all MGMG adopted villages of the district comes under Nambol Block hence sufficient nos. of respondent are available to conduct the study.

\section{Selection of villages}

The list of villages adopted under MGMG Programme out of the fourteen villages of Nambol block was obtained from College of Agriculture, CAU, Imphal and were selected purposively as all the beneficiaries in Bishnupur District belong to these villages only.

\section{Selection of respondents}

A list of beneficiaries and adopters of the MGMG programme from the villages adopted under the same were obtained from the College of Agriculture, CAU, Imphal and District Agricultural Office (DAO), Bishnupur District respectively. A total of 120 farmers combining all the beneficiaries and adopters were selected by using purposive sampling and simple random sampling method respectively- Leimaram Mayai Leikai village (40), Kabowakching village (40), Heinoubok village (40).

\section{Results and Discussion}

The characteristics selected to study the socio-personal profile of MGMG farmers were age, education, land holding, organizational participation, farming experience, innovation proneness, risk orientation, mass media exposure, source of information, extension contact, annual income and economic motivation.

\section{Age}

Table-1 showed that majority of the respondents were middle aged $(60.00 \%)$ followed by young aged $(22.50 \%)$ and old aged $(17.50 \%)$.

The possible reason supporting this result could be that most young farmers have been engaged in other non- agricultural activities and are considered as the most mobile group. They prefer to pursue higher education and other type of business.

Whereas, old age farmers may no longer be active to participate in farming activities and they prefer to stay within the comfort of their homes. Contrarily, middle aged farmers were more skillful, enthusiastic to increase their production level and annual income. They were also more spirited to gain new knowledge about scientific agriculture in comparison to young and old aged farmers. Similar findings were derived by Ramu (2005) and Dadarao (2013).

\section{Education}

Table-2 indicated that all of the respondents had received some form of education. Most of respondents were seen to be educated up to high school (51.67\%) followed by preuniversity course $(34.16 \%)$ which could be ascertained to better interventions and educational facilities by government. The 
potential reason for this trend might be that a greater proportion of the farmers were enthusiastic for better educational qualification and lifestyle.

There were only 7.50 per cent respondents educated upto graduation and none in post graduation which might be due to lack of higher educational institute. Whereas only 6.67 per cent respondents were educated upto middle school which might be ascertained to financial barriers.

\section{Land holding}

Table- 3 showed that a huge proportion of the respondents were small farmers $(72.50 \%)$ followed by marginal farmers $(26.67 \%)$. Only 0.83 per cent respondents were semi-medium farmers. As nuclear family system is prevalent in the study area, the fragmentation of land holding among the family members might be the sole reason for most of the respondents to be small and marginal farmers. Similar findings were reported by Patil (2000) and Shashidhara (2003).

Table.1 Distribution of respondents according to their age $(n=120)$

\begin{tabular}{|c|l|c|c|}
\hline Sl. No. & \multicolumn{1}{|c|}{ Category } & Frequency & Percentage \\
\hline 1. & Young age (Up to 35 years) & 27 & 22.50 \\
\hline 2. & Middle age (36 to 56 years) & 72 & 60.00 \\
\hline 3. & Old age (Above 56 years) & 21 & 17.50 \\
\hline & Total & 120 & 100 \\
\hline
\end{tabular}

Table.2 Distribution of respondents according to their education $(n=120)$

\begin{tabular}{|c|l|c|c|}
\hline Sl. No. & \multicolumn{1}{|c|}{ Category } & Frequency & Percentage \\
\hline $\mathbf{1 .}$ & Illiterate & 0 & 0 \\
\hline $\mathbf{2 .}$ & Primary School & 0 & 0 \\
\hline $\mathbf{3 .}$ & Middle School & 8 & 6.67 \\
\hline $\mathbf{4 .}$ & High School & 62 & 51.67 \\
\hline $\mathbf{5 .}$ & Pre-University Course & 41 & 34.16 \\
\hline $\mathbf{6 .}$ & Graduation & 9 & 7.50 \\
\hline $\mathbf{7 .}$ & Post graduation & 0 & 0 \\
\hline & Total & 120 & 100 \\
\hline
\end{tabular}

Table.3 Distribution of respondents according to their size of land holding $(n=120)$

\begin{tabular}{|c|l|c|c|}
\hline Sl. No. & \multicolumn{1}{|c|}{ Category } & Frequency & Percentage \\
\hline 1. & Marginal farmers (upto 2.5 acres) & 32 & 26.67 \\
\hline 2. & Small farmers (2.51- 5.00 acres) & 87 & 72.50 \\
\hline 3. & Semi-Medium farmers $(5.01-10.00$ acres) & 1 & 0.83 \\
\hline 4. & Medium farmers (10.01- 25.00 acres) & 0 & 0 \\
\hline 5. & Big farmers (Above 25.00 acres) & 0 & 0 \\
\hline & Total & 120 & 100 \\
\hline
\end{tabular}


Table.4 Distribution of respondents according to their organizational participation $(n=120)$

\begin{tabular}{|c|l|c|c|}
\hline Sl. No. & \multicolumn{1}{|c|}{ Category } & Frequency & Percentage \\
\hline 1. & Low (Mean - S.D.) & 17 & 14.17 \\
\hline 2. & Medium (Mean \pm S.D.) & 82 & 68.33 \\
\hline 3. & High (Mean + S.D.) & 21 & 17.50 \\
\hline & Total & 120 & 100 \\
\hline
\end{tabular}

Mean $=12.14$ S.D. $=1.56$

Table.5 Distribution of respondents according to their farming experience $(n=120)$

\begin{tabular}{|c|l|c|c|}
\hline Sl. No. & \multicolumn{1}{|c|}{ Category } & Frequency & Percentage \\
\hline $\mathbf{1 .}$ & Low (<9 years) & 13 & 10.83 \\
\hline $\mathbf{2 .}$ & Medium (9-26 years) & 88 & 73.34 \\
\hline 3. & High $(>26$ years $)$ & 19 & 15.83 \\
\hline & Total & 120 & 100 \\
\hline
\end{tabular}

Mean=17.63 S.D. $=8.75$

Table.6 Distribution of respondents according to their innovation proneness $(n=120)$

\begin{tabular}{|c|l|c|c|}
\hline Sl. No. & \multicolumn{1}{|c|}{ Category } & Frequency & Percentage \\
\hline 1. & Low (Mean - S.D.) & 20 & 16.67 \\
\hline 2. & Medium (Mean \pm S.D. $)$ & 79 & 65.83 \\
\hline 3. & High (Mean + S.D.) & 21 & 17.50 \\
\hline & Total & 120 & 100 \\
\hline
\end{tabular}

Mean=39.28 S.D. $=7.54$

Table.7 Distribution of respondents according to their risk orientation $(n=120)$

\begin{tabular}{|c|l|c|c|}
\hline Sl. No. & \multicolumn{1}{|c|}{ Category } & Frequency & Percentage \\
\hline 1. & Low $($ Mean - S.D.) & 12 & 10.00 \\
\hline 2. & Medium (Mean \pm S.D.) & 83 & 69.17 \\
\hline 3. & High (Mean + S.D.) & 25 & 20.83 \\
\hline & Total & 120 & 100 \\
\hline
\end{tabular}

Mean=13.41 S.D. $=2.33$

Table.8 Distribution of respondents according to their mass media exposure

\begin{tabular}{|c|l|c|c|}
\hline Sl. No. & \multicolumn{1}{|c|}{ Category } & Frequency & Percentage \\
\hline 1. & Low (Mean - S.D.) & 19 & 15.83 \\
\hline 2. & Medium (Mean + S.D.) & 86 & 71.67 \\
\hline 3. & High (Mean + S.D.) & 15 & 12.50 \\
\hline & Total & 120 & 100 \\
\hline
\end{tabular}

Mean=40.19 S.D.=3.53 
Table.9 Distribution of respondents according to their source of information $(n=120)$

\begin{tabular}{|c|c|c|c|c|c|c|c|}
\hline \multirow{3}{*}{$\begin{array}{c}\text { Sl. No. } \\
1 .\end{array}$} & \multirow{3}{*}{\begin{tabular}{|c|} 
Sources \\
Officials of MGMG \\
\end{tabular}} & \multicolumn{6}{|c|}{ Frequency \& percentage of use by respondent } \\
\hline & & \multicolumn{2}{|c|}{ Regular } & \multicolumn{2}{|c|}{ Occasional } & \multicolumn{2}{|c|}{ Never } \\
\hline & & 48 & 40.00 & 69 & 57.50 & 3 & 2.50 \\
\hline 2. & DAO, Bishnupur & 4 & 3.33 & 36 & 30.00 & 80 & 66.67 \\
\hline 3. & CAU, Imphal & 45 & 37.50 & 73 & 60.83 & 2 & 1.67 \\
\hline 4. & SMSs of KVKs & 4 & 3.33 & 57 & 47.50 & 59 & 49.17 \\
\hline 5. & Progressive farrmers & 79 & 65.83 & 40 & 33.33 & 1 & 0.83 \\
\hline 6. & Radio & 83 & 69.17 & 36 & 30.00 & 1 & 0.83 \\
\hline 7. & News paper & 54 & 45.00 & 47 & 39.17 & 19 & 15.83 \\
\hline 8. & Farm magazine & 35 & 29.17 & 56 & 46.67 & 29 & 24.17 \\
\hline 9. & TV & 55 & 45.83 & 47 & 39.17 & 18 & 15.00 \\
\hline
\end{tabular}

Table.10 Distribution of respondents according to their extension contact $(n=120)$

\begin{tabular}{|c|l|c|c|}
\hline Sl. No. & \multicolumn{1}{|c|}{ Category } & Frequency & Percentage \\
\hline 1. & Low (Mean - S.D.) & 10 & 8.33 \\
\hline 2. & Medium (Mean + S.D.) & 68 & 56.67 \\
\hline 3. & High (Mean + S.D.) & 42 & 35.00 \\
\hline & Total & 120 & 100 \\
\hline
\end{tabular}

Mean=10.85 S.D. $=1.57$

Table.11 Distribution of respondents according to their annual income $(n=120)$

\begin{tabular}{|c|l|c|c|}
\hline Sl. No. & \multicolumn{1}{|c|}{ Category } & Frequency & Percentage \\
\hline 1. & Low (Mean - S.D.) & 2 & 1.67 \\
\hline 2. & Medium (Mean + S.D.) & 101 & 84.17 \\
\hline 3. & High (Mean + S.D.) & 17 & 14.16 \\
\hline & Total & 120 & 100 \\
\hline
\end{tabular}

Mean $=48.28$ S.D. $=16.32$

Table.12 Distribution of respondents according to their economic motivation $(n=120)$

\begin{tabular}{|c|l|c|c|}
\hline Sl. No. & \multicolumn{1}{|c|}{ Category } & Frequency & Percentage \\
\hline 1. & Low (Mean - S.D.) & 20 & 16.67 \\
\hline 2. & Medium (Mean \pm S.D.) & 71 & 59.17 \\
\hline 3. & High (Mean + S.D.) & 29 & 24.16 \\
\hline & Total & 120 & 100 \\
\hline
\end{tabular}

Mean=17.76 S.D. $=2.06$

\section{Organizational participation}

Table-4 pointed out that majority of the respondents had medium level of organizational participation $(68.33 \%)$ followed by a close proportion of the farmer having high $(17.50 \%)$ and low $(14.17 \%)$ level of organization participation. The possible 
explanation might be that most of these organizations were either less functional or inactive and thus the respondents were not interested to visit and participate. The respondents having high level of organizational participation were active participant and visitor of their respective village gram panchayat and farmer's club.

\section{Farming experience}

Table-5 indicated that majority of the respondent had medium level of farming experience $(73.34 \%)$ followed by high $(15.83 \%)$ and low (10.83\%) which might be because of the fact that majority of the respondents were in middle age group who might have started farming at an young age and hence they had medium farming experience whereas 15.83 per cent of respondents had high farming experience might be because they had practiced farming throughout their adulthood. Similar findings were derived by Raghavendra (2007).

\section{Innovation proneness}

The highest proportion of respondents had medium innovation proneness $(65.83 \%)$ followed by distributions of respondents with high innovation proneness $(17.50 \%)$ and low innovation proneness $(16.67 \%)$ as shown in Table-6. The possible reason behind this might be that majority of respondents were in middle age group who had medium level of education and medium extension contact. As a result, they were quite keen and enthusiastic to adopt new technologies. Similar findings were reported by Ramu (2005).

\section{Risk orientation}

Table-7 pointed that most of the respondents had medium risk orientation (69.17\%). It was followed by high risk orientation (20.83\%) and low risk orientation $(10.00 \%)$. The reason for such trend might be due to the sociopersonal characters of the respondents. Similar findings were derived by Natikar (2001) and Deepak (2003).

\section{Mass media exposure}

Table- 8 showed that majority of the farmers had medium mass media exposure $(71.67 \%)$ whereas the other respondents had low $(15.83 \%)$ and high (12.50\%) mass media exposure. The reason behind a huge proportion of respondents having medium mass media exposure might be that majority of them were curious and anxious to know about their surroundings and latest happening and events pertaining to their area of interest. Similar findings were reported by Shashidhara (2003) and Vedamurthy (2002).

\section{Source of Information}

Table-9 revealed Radio as the most used source of information on regular basis whereas DAO, Bishnupur was never used as source of information by majority of respondents i.e. 69.17 per cent and 66.67 per cent respectively. CAU, Imphal was preferred by majority of respondents $(60.83 \%)$ as an occasionally used source of information. Radio being source of diverse kind of information along with information pertaining to agricultural field and available at cheaper cost might be ascertained as the reason for such distribution.

A gap of communication between the officials of DAO and the respondents might be held the reason behind lack of regular meetings, trainings etc and hence never used by most of the farmers. As the implementing agency of the MGMG programme is CAU, Imphal it might be considered as the best source of information for occasional use by majority of respondents. 


\section{Extension contact}

Table-10 pointed out that majority of respondents had medium $(56.67 \%)$ followed by high $(35.00 \%)$ and low $(8.33 \%)$ level of extension contact. This might be because of the fact that majority of the respondents had a good educational level and medium mass media exposure hence might have more information and knowledge related to the extension agencies and ways to approach the extension personnel. Similar findings were reported by Sridhara (2002).

\section{Annual income}

Table-11 pointed out that majority of the respondents had medium $(84.17 \%)$ followed by high (14.16\%) and low (1.67\%) level of annual income. The potential reason behind such trend might be that they were also participating in additional income generation activities other than farming. It might also be attributed to the better utilization of farming resources done in IFS along with practicing non-farming activities. Similar findings were derived by Sridhara (2002).

\section{Economic motivation}

Table-12 exhibited that majority of the respondents had medium level of economic motivation $(59.17 \%)$ followed by 24.16 per cent of respondents who had high economic motivation and 16.67 per cent of respondents who had low level of economic motivation. The reason behind this distribution could be due to narrow range of opportunities at ground level and subsistence look of agriculture at village level. Similar findings were derived from Bheemappa (2001).

Finally, it can be concluded that there is a positive significant improvement in the socioeconomic status after implementation of IFS under MGMG which has a scope for policy makers to promote similar programs in other blocks and districts. The participatory approach of the respondents was found encouraging in all stages of implementation which enables agencies to take up mass development in rural areas. The results revealed a positive significant impact of IFS on increasing the annual income and hence needs to be continued and extended. The study indicated that, the MGMG beneficiaries who have adopted the IFS conveyed the importance of the programme in improving the socio-economic status. Hence, the institutions involved in development of such programmes may follow the approach of MGMG for better improvement. The research study pointed out that, the financial assistance may be coupled with technical guidance for increasing the standards of living of rural people.

\section{Acknowledgements}

I avail this opportunity to extend my heartfelt gratitude to my major Advisor, Dr. Daya Ram, Assistant Professor, Department of Agricultural Extension, College of Agriculture, Central Agricultural University, Imphal for his guidance, constant supervision, innovative ideas and thoughtful suggestions at the most crucial moment which have been invaluable towards the timely and successful completion of this study. I am extremely grateful to the members of my Advisory committee, Dr. M. Kunjaraj Singh, Dr. Y. Chakrabarty Singh and Dr. N. Okendro Singh for their worthy guidance, helpful suggestions and encouragement throughout the course of my research work.

\section{References}

Anonymous. (2019). Agriculture in India. Wikipedia. https://en.m.wikipedia.org/wiki/Agricult ure_in_India.Accessed 19 August 2019. 
Bheemappa, A. (2001). A comparative analysis of knowledge and technological gap adoption of paddy and cotton cultivation practices between migrant and non-migrant farmers of TBP command area in Karnataka. Ph. D. Thesis, Submitted to University of Agricultural Sciences, Dharwad, Karnataka, India.

Dadarao, O. N. (2013). Adoption of improved cultivation practices of turmeric by the farmers. Doctoral Dissertation, Submitted to Dr. Panjabrao Deshmukh Krishi Vidyapeeth, Akola, Maharashtra.

Deepak, M. P. (2003). A study on perception on beneficiaries and non-beneficiaries towards WYTEP programme in Dharwad district. M. Sc. (Agri.) Thesis, Submitted to University of Agricultural Sciences, Dharwad, Karnataka.

Natikar, K. V. (2001). Attitude and use of farm journal by the subscriber farmers and their profile. A critical analysis. Ph. D.Thesis, Submitted to University of Agricultural Sciences, Dharwad, Karnataka.

Patil, P. G., Borse, V. V. and Khade, P. B. (2000). Correlates of knowledge and adoption of Kokani tribal farmers. Tribal Research Bulletin, 22(1):30-35.

Raghavendra, N. (2007). A study on management practices of pineapple growers in Karnataka. M. Sc. (Agri.) Thesis, Submitted to University of Agricultural Sciences, Dharwad, Karnataka.

Ramu, A.G. (2005). Knowledge and adoption of turmeric farmers in Kadapa District of Andhra. Doctoral Dissertation, Submitted to Acharya N.G. Ranga Agricultural University, Guntur, Andhra Pradesh.

Shashidhara, K. K. (2003). A study on socioeconomic profile of drip irrigation farmers in Shimoga and Davangere district of Karnataka. M. Sc. (Agri.) Thesis, Submitted to University of Agricultural Sciences, Dharwad, Karnataka.

Sridhara, K. (2002). An evaluative study of watershed programme in Pavagadataluk of Tumkur district in Karnataka. M. Sc. (Agri.) Thesis, Submitted to University of Agricultural Sciences, Dharwad, Karnataka.

Vedamurthy, H. J. (2002). A study on the management of areca gardens and marketing pattern preferred by the arecanut farmers of Shivamoga district in Karnataka. M. Sc. (Agri.) Thesis, Submitted to University of Agricultural Sciences, Dharwad, Karnataka.

\section{How to cite this article:}

Suparna Dey, Daya Ram, M. Kunjaraj Singh and N.Okendro Singh. 2021. Impact of Integrated Farming System on the Socio-Economic Status of Farmers under 'Mera Gaon Mera Gaurav (MGMG)'Programme in Bishnupur District of Manipur, India. Int.J.Curr.Microbiol.App.Sci. 10(10): 622-630. doi: https://doi.org/10.20546/ijcmas.2021.1010.072 